$\underline{\xi}=-m$

\title{
The possible protective role of green tea extract on the intestinal mucosal changes induced by fluoride on adult albino rats
}

\author{
Sahar M. Abo El Wafa ${ }^{1}$ *, Eman Abdel-Mohsen Abdel-Aziz ${ }^{2}$, Lamiaa M. Shawky ${ }^{3}$, Mariam S. Zaki ${ }^{4}$ \\ ${ }^{1}$ Department of Forensic Medicine and Clinical Toxicology, Faculty of Medicine, Benha University, Benha, Egypt \\ ${ }^{2}$ Department of Pharmacology, Faculty of Medicine, Benha University, Benha, Egypt \\ ${ }^{3}$ Department of Histology and Cell Biology, Faculty of Medicine, Benha University, Benha, Egypt \\ ${ }^{4}$ Department of Public Health Community and Occupational Medicine, Faculty of Medicine, Benha University, Benha, Egypt \\ *Corresponding author E-mail: saharabouelwafa32@yahoo.com
}

\begin{abstract}
Background: Fluoride is an inorganic element present everywhere in the environment and has cumulative toxic effects from prolonged ingestion. Green tea used since ancient times as a medical drink due to its multiple health benefits owing to its anti-oxidative and antiapoptotic activities. Aim: To the best of our knowledge there were no studies until now concerning the possible protective role of green tea extract on the intestinal mucosal changes induced by fluoride on adult albino rats, so this work tried to investigate this role. Materials and Methods: Forty male adult albino rats randomly and equally divided into four groups, Group I: received distilled water only orally via a gastric tube. Group II: received green tea extract (GTE) $150 \mathrm{mg} / \mathrm{kg}$ dissolved in distilled water and freshly prepared for 35 days. Group III: received sodium fluoride $(\mathrm{NaF})$ once daily oral dose of $10 \mathrm{mg} / \mathrm{kg}$ dissolved in distilled water for 35 days. Group IV: received $\mathrm{NaF}$ in the same dose as group III concomitant with GTE as the previously adjusted dose for 35 days. Body weight of all the studied groups was recorded at the start and after 35 days from the beginning of this study. After that the study tested the antioxidant and oxidant parameters in intestinal tissue as MDA, reduced GSH, and CAT, histopathological and immunohistochemical examination of intestinal tissue using PCNA marker were also included. Results: the rate of weight gain was little in NaF group compared to other groups. Concomitant administration of GTE with NaF resulted in highly significant decrease in MDA level, highly significant increase in reduced GSH level and highly significant elevation in CAT level when compared with NaF group. Many of abnormalities as moderate increase in goblet cell mass and highly expression of PCNA stain in a form of brown nuclear coloration were detected in intestinal tissues in NaF group by histopathological and immunohistochemical study that improved with administration of GTE. Conclusion: concomitant administration of GTE was improved the biochemical, histopathological and immunohistochemical alterations in intestinal mucosa that treated with $\mathrm{NaF}$.
\end{abstract}

Keywords: Antioxidant; Fluoride; Green Tea Extract; Intestinal Mucosa.

\section{Introduction}

Fluoride is an inorganic anion element present everywhere in the environment and has a highly prophylactic effect at low concentrations by preventing dental caries, while at high concentrations it causes harmful effects as dental and skeletal fluorosis (Chachra et al., 2008; Ozsvath, 2009).

Fluoride also has cumulative toxic effects from prolonged ingestion that lead to fluorosis which is a condition persistent especially in third world where people have little choice of the main source of drinking water that is often contaminated with fluoride, water supplies, dietary ingredients, dental products, industrial emissions and occupational exposure which is higher than the safe dose (Ozsvath, 2009). Fluoride crosses the cell membrane very rapidly and distributed from the plasma to all tissue and organs (Bouaziz et al., 2006). Fluoride in high concentration also founded to affect memory function in some experimental animals and causing dysfunctions of the central nervous system and decrease learning ability. Epidemiological studies reveal that intelligence quotient of children living in endemic fluorosis places are lower than that of children living in low fluoride places (Xiang et al., 2003; Wang et al., 2007; Ozsvath, 2009).

In general tea is the most popular beverage, after water, drunken by more than $2 / 3$ of the world's population. It is rich in substances with antioxidant properties and has little proteins, amino acids, lipids and some vitamins and minerals (Gupta et al., 2002). The tea leaves are characterized by their content of methylxanthines and polyphenols especially flavonols of the catechin type (Finkel and Holbrook, 2000; Perwez et al., 2003; Barnham et al., 2004).

Green Tea consumption has linked to regress various forms of diseases as cancer, diabetes, depression, cardiovascular and neurological disorders due to its antioxidative, antiapoptotic activities (Khan and Mukhtar, 2007; Rameshrad et al., 2017). 
Green tea polyphenols found to inhibit growth of stomach cancer and gastritis and regulate intestinal functions (Shimizu, 1999). Green tea catechins also founded to protect GIT mucosa and prevent intestinal atrophy (Asfar et al., 2003). Green tea catechins improve gut flora by increase the growth of the bacteria in the gut wall and decrease the levels of violent pathogens (Goto et al., 1998).

To the best of our knowledge, there are no studies concerning the toxic effects of chronic exposure to sodium fluoride (NaF) on the intestine of albino rats and the impact of synchronous administration of green tea extract as antioxidant therapy, therefore, this study tried to evaluate the possible protective role of green tea extract on the intestinal mucosal changes induced by fluoride on adult male albino rats.

\section{Materials and methods}

\subsection{Drugs and chemicals}

1) Green tea extract (GTE) was purchased from Technomed Groups Company, Egypt, "in the form of tablets (200 mg)". The tablets were dissolved in distilled water.

2) Sodium Fluoride (NaF) was obtained from El-Gomhoria Co. for Chemical Products, Al-Amyeria, Cairo, Egypt as NaF powder which is white water-soluble powder.

3) Nuclear Antigen (PCNA): PCNA monoclonal antibody (clone pc 10) was purchased from Lab Vision USA by Medico Trade Company, Giza, Egypt.

4) All kits used for different oxidative/antioxidative markers (malondialdehyde MDA; glutathione GSH; and catalase CAT) were purchased from Laboratory BioDiagnostics Co.,Giza, Egypt.

\subsection{Animals}

Forty male adult albino rats weighing 200-250 g were obtained from Experimental Animal Breeding Farm, (Helwan-Cairo). They were caged 10 per cage in well-ventilated place at room temperature in the animal house at the Department of pharmacology, Benha Faculty of Medicine for 2 weeks of acclimatization. They allowed free water and standard food (pellets specific for rat feeding obtained from the animal breeding farm) on a schedule of 12 hours of light and 12 hours of dark. The time of dose administration was fixed for all animals at 12 P.M. During the whole period of experiment, animals were treated humanely according to the protocol of handling of experimental animals of Benha Faculty of Medicine.

\subsection{Study design}

Forty adult male rats randomly divided into four groups, each consisted of 10 animals, and distributed as follows:

Group I: Rats received distilled water only orally via a gastric tube.

Group II: Rats received green tea extract (GTE) $150 \mathrm{mg} / \mathrm{kg}$ body weight dissolved in distilled water and freshly prepared for 35 days (Hamdy et al., 2012).

Group III: Rats received sodium fluoride $(\mathrm{NaF})$ once daily oral dose of $10 \mathrm{mg} / \mathrm{kg}$ body weight dissolved in distilled water and freshly prepared. Each gram of $\mathrm{NaF}$ was dissolved in $100 \mathrm{ml}$ of distilled water to obtain a solution of concentration of $10 \mathrm{mg} \mathrm{NaF} / \mathrm{ml} \mathrm{water} \mathrm{for}$ 35 days (Błaszczyk et al., 2008).

Group IV: Rats received sodium fluoride $(\mathrm{NaF})$ in the same dose as group III concomitant with GTE as the previously adjusted dose for 35 days.

\subsection{Procedural details}

\subsubsection{Body weight}

Body weight of control, GTE, NaF and $(\mathrm{GTE}+\mathrm{NaF})$ treated rats were recorded at the start of the study and after 35 days from the beginning of this study.

After 35 days from the beginning of experiment, both control and the studied groups were sacrificed by inhalation of high dose of ether and the abdomen was explored; the intestine specimens were rapidly removed and subjected to the following techniques:

\subsubsection{Tissue oxidative stress parameters}

1) MDA assay: İntestinal tissue samples were irrigated with a solution of sodium chloride $0.9 \%$ and with potassium chloride $1.5 \%$, homogenization at a ratio of 1:10 was achieved. The lipid peroxide level in the centrifuged tissue homogenates was measured according to the method described by Ohkawa et al. (1979). The reaction product was assayed spectrophotometrically at $532 \mathrm{~nm}$. The lipid peroxide level was expressed as the nmol of MDA/ mg of intestinal tissue protein. Protein levels were measured according to the method described by Lowry et al. (1951).

2) Reduced GSH: reduced GSH content was determined with dithionitrobenzoic acid using the method described by (Beutler et al., 1963) and was expressed in $\mu \mathrm{mol} \mathrm{GSH} / \mathrm{mg}$ protein. The method is based on the reduction of DTNB to produce a yellow compound. The reduced chromogen is directly proportional to GSH concentration and its absorbance can be measured at $412 \mathrm{~nm}$.

3) Catalase: The catalase (CAT) activity was measured by monitoring $\mathrm{H} 2 \mathrm{O} 2$ decomposition at $240 \mathrm{~nm}$ according to the method described by Aebi (Aebi, 1984).

\subsubsection{Histopathological study}

Immediately after scarifications of animals and dissection, intestine from different groups were quickly removed, washed in 0.9 saline solutions and samples of intestine were fixed in $10 \%$ neutral buffered formalin. After fixation, specimens were dehydrated in an ascending series of alcohol, cleared in two changes of xylene and embedded in molten paraffin (mp. 50-58 ${ }^{\circ} \mathrm{C}$. Sections of 7 microns thickness were cut using rotary microtome and mounted on clean slides. Sections were stained with Ehrlich's haematoxylin and counterstained with eosin as a routine method of Bancroft and Stevens (Bancroft and Stevens, 1990). 


\subsubsection{Immunohistochemical study using proliferating cell nuclear antigen (PCNA)}

Paraffin blocks were prepared from intestines already fixed in $10 \%$ formalin for two days. Paraffin sections were stained with avidin biotin peroxidase technique for proliferating cell nuclear antigen (PCNA) using the method described by (Bancroft and Stevens, 1996; Hall et al., 1990)

\subsection{Statistical analysis}

The collected data were tabulated and analyzed using SPSS (Statistical package for social science) version 20. Data were presented as mean and standard deviation for quantitative data, frequency, and distribution for qualitative data. They were tested using ANOVA test (F value) used to compare mean of more than two groups of quantitative data with using post hoc test (LSD) for inter-group comparison, corrected chi-square test used for Inter-group comparison of categorical data. The accepted level of significance in this work was started at 0.05 (Greenberg et al., 1996).

\section{Results}

\subsection{Body weight measurements}

Body weights of all groups were recorded at the beginning of the study and after 35 days of the treatment. Table (1) shows the mean of the initial and final body weights (g). On average, the rats of all groups gained weight throughout the experimental period, when compared to the initial body weight. At the beginning of the study, mean initial body weight showed non-significant difference between the studied groups ( $p>0.05$ ) while at the end of the study (after 35th day) the final body weight was significantly ( $<<0.05)$ higher in all groups compared to initial body weight with high significant $(\mathrm{p}<0.001)$ increase in final body weight in control and GTE groups compared to $\mathrm{NaF}$ group with significantly $(\mathrm{P}<0.05)$ increase in final body weight in $(\mathrm{NaF}+\mathrm{GTE})$ group versus NaF group and nonsignificantly increase in final body weight in control versus GTE group.

\subsection{Tissue oxidative stress parameters}

As regarding mean Malondialdehyde (MDA) level, there was a considerable decrease in MDA level in GTE group when compared to the control group, while $\mathrm{NaF}$ administration resulted in highly significant increase in MDA level when compared to both the control and GTE group. Concomitant administration of GTE with $\mathrm{NaF}$ in the (NaF GTE) group resulted in great improvement representing in a highly significant decrease in MDA level as compared with $\mathrm{NaF}$ group (Table 2).

Regarding mean reduced GSH level, there was a highly significant rise in reduced GSH level in GTE treated rats as compared to control group; $\mathrm{NaF}$ administration resulted in highly significant decrease in reduced GSH level as compared to control and GTE group. Concomitant administration of GTE with $\mathrm{NaF}$ leads to highly significant increase in reduced GSH level when compared with $\mathrm{NaF}$ group but still highly significant lower than the control and GTE groups (Table 3).

Regarding mean catalase (CAT) level, there was a highly significant rise in CAT level in GTE treated rats as compared to control group; $\mathrm{NaF}$ administration resulted in highly significant decrease in CAT level as compared to control and GTE group. Concomitant administration of GTE with NaF leads to highly significant elevation in CAT level when compared with NaF group but still highly significant lower than the control and GTE groups (Table 4).

\subsection{Histopathological changes of the intestinal mucosa of the studied groups}

The changes in the intestinal mucosa of the studied groups were detected by histopathological examination using Hematoxylin and Eosin stain. Examination of Hematoxylin and Eosin stained sections of intestinal mucosa in group I show normal structure of intestine (crypts of Lieberkuhn) and goblet cells are the most cells lining the crypts (Fig.1). Group II shows some crypts with crowded villi and dilated lumen mainly in their basal parts (Fig. 2) while group III shows moderate increase in goblet cell mass (Fig. 3) and group IV showed mild increases in goblet cell mass (Fig. 4).

\subsection{Immunohistochemical results}

Changes in the intestinal mucosa of the studied groups were examined immunohistochemical by Proliferating Cell Nuclear Antigen (PCNA) marker to detect proliferating changes that occur in the nucleus. PCNA known as a regulated nuclear protein for DNA polymerase and the PCNA-labeled nuclei identify the cells in the late G1 and early S phases of the cell cycle and the cells subjected to DNA repair. PCNA expression was used as an index for these changes by counting the average number of the stained nucleus that attained brown coloration in relation to the number of the nucleus that not gain this brown coloration in the stained field and classified accordingly to low, moderate and high PCNA expression.

Group 1 showed low expression of PCNA stain in the form of brown nuclear coloration (Fig. 5). GroupII showed low expression of PCNA stain in a form of brown nuclear coloration (Fig. 6). Group III showed highly expression of PCNA stain in a form of brown nuclear coloration (Fig. 7). Group IV showed moderate expression of PCNA stain in form of brown nuclear coloration (Fig. 8).

Table 1: Statistical Comparison between All Studied Groups Regarding Body Weight by ANOVA Test

\begin{tabular}{|c|c|c|c|c|c|c|}
\hline Groups & & Mean \pm SD & Minimum & Maximum & F test & p-value \\
\hline \multirow{4}{*}{ At the start of the study } & Group I & $222.9 \pm 17.2$ & 200 & 250 & \multirow{4}{*}{.434} & \multirow{4}{*}{$>0.05$} \\
\hline & Group II & $215.7 \pm 12$ & 200 & 230 & & \\
\hline & Group III & $217.5 \pm 16.7$ & 200 & 250 & & \\
\hline & Group IV & $217.1 \pm 14.3$ & 200 & 240 & & \\
\hline \multirow{4}{*}{ After 35 days } & Group I & $253.8 \pm 17.1$ & 232 & 285 & \multirow{4}{*}{5.59} & \multirow{4}{*}{$<0.05^{*}$} \\
\hline & Group II & $252.7 \pm 13$ & 238 & 275 & & \\
\hline & Group III & $229.1 \pm 16.6 \$^{\wedge * *}$ & 211 & 262 & & \\
\hline & Group IV & $243.3 \pm 14 € *$ & 226 & 266 & & \\
\hline
\end{tabular}


All values are expressed as mean \pm SD.

Number of rats in each group $=10$.

Significant $(*)$ highly significant $(* *)$

$\$$ : indicate significant change as compared with a group (I).

$\wedge$ : indicate significant change as compared with a group (II).

$€$ : indicate significant change as compared with a group (III)

$\mathrm{F}$ test $=$ ANOVA test

Table 2: Statistical Comparison between All Studied Groups Regarding MDA by ANOVA Test

\begin{tabular}{|c|c|c|c|}
\hline Groups & MDA level ( $\mathrm{n}$ mol / mg protein) Mean \pm SD & F test & $\mathrm{P}$ value \\
\hline $\begin{array}{l}\text { G I } \\
\text { (Control group) }\end{array}$ & $88.7 \pm 3.57$ & \multirow{4}{*}{5.7} & \multirow{4}{*}{$<0.001 * *$} \\
\hline $\begin{array}{l}\text { G II } \\
\text { (Green Tea Extract group) }\end{array}$ & $84.2 \pm 0.9 \$ *$ & & \\
\hline $\begin{array}{l}\text { G III } \\
\text { (NaF group) }\end{array}$ & $280.2 \pm 5.9 \$^{\wedge * *}$ & & \\
\hline $\begin{array}{l}\text { G IV } \\
(\mathrm{NaF}+\mathrm{GTE})\end{array}$ & $150.1 \pm 3.2 \$^{\wedge} €^{* *}$ & & \\
\hline
\end{tabular}

All values are expressed as mean $\pm \mathrm{SD}$

Number of rats in each group $=10$

Significant $(*)$ highly significant $(* *)$

$\$$ : indicate significant change as compared with a group (I)

$\wedge$ : indicate significant change as compared with a group (II)

$€$ : indicate significant change as compared with a group (III)

$F$ test $=$ ANOVA test

Table 3: Statistical Comparison between All Studied Groups Regarding GSH by ANOVA Test

\begin{tabular}{ll}
\hline Groups & GSH $(\mu \mathrm{mol} / \mathrm{mg}$ protein $)$ Mean \pm SD \\
\hline G I & $275 \pm 9.8$ \\
(Control group) & $330 \pm 6 \$^{* *}$ \\
G II & \\
(Green Tea Extract group) & $140 \pm 3.8 \$^{\wedge * *}$ \\
G III & $200 \pm 5.7 \$ \$^{* * *}$ \\
(NaF group) & $<$ IV \\
(NaF+ GTE) & 2.6 \\
\hline
\end{tabular}

All values are expressed as mean \pm SD.

Number of rats in each group $=10$.

Significant $(*)$ highly significant $(* *)$

$\$$ : indicate significant change as compared with a group (I).

$\wedge$ : indicate significant change as compared with a group (II).

$€$ : indicate significant change as compared with a group (III).

$\mathrm{F}$ test $=$ ANOVA test

Table 4: Statistical Comparison between All Studied Groups Regarding CAT by ANOVA Test

\begin{tabular}{ll}
\hline Groups & CAT $(\mathrm{m} \mathrm{mol} / \mathrm{min} / \mathrm{mg}) \mathrm{Mean} \pm \mathrm{SD}$ \\
\hline G I & $52 \pm 2.8$ \\
(Control group) & $60 \pm 2.2 \$^{* *}$ \\
GI & \\
(Green Tea Extract group) & $20 \pm 2.4 \$^{\wedge * *}$ \\
G III & \\
(NaF group) & $35 \pm 3.5 \$^{\wedge} €^{* *}$ \\
\hline (NaF+ GTE) & $<0.001^{* *}$
\end{tabular}

All values are expressed as mean \pm SD.

Number of rats in each group $=10$.

Significant $(*)$ highly significant $(* *)$

$\$$ : indicate significant change as compared with a group (I).

$\wedge$ : indicate significant change as compared with a group (II).

$€$ : indicate significant change as compared with a group (III).

$\mathrm{F}$ test $=$ ANOVA test.

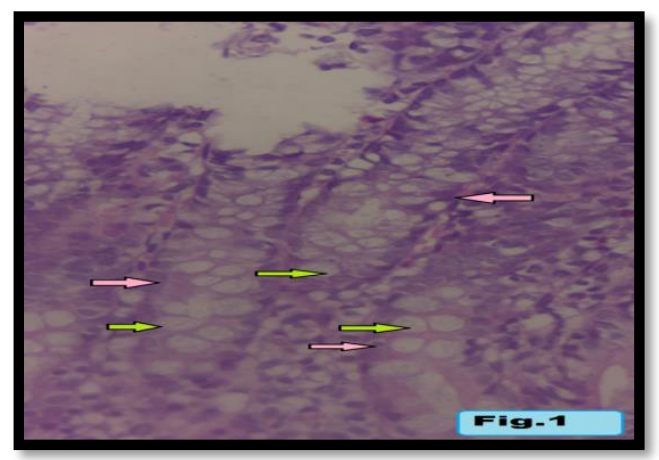

Fig. 1: A Slide of an Adult Rat Intestine in (Group I) Shows Normal Structure of Intestine (Crypts of Lieberkuhn) (Pink Arrows) and Goblet Cells are the Most Cells Lining the Crypts (Green Arrows) (Hematoxylin \& Eosin Stain X 40). 


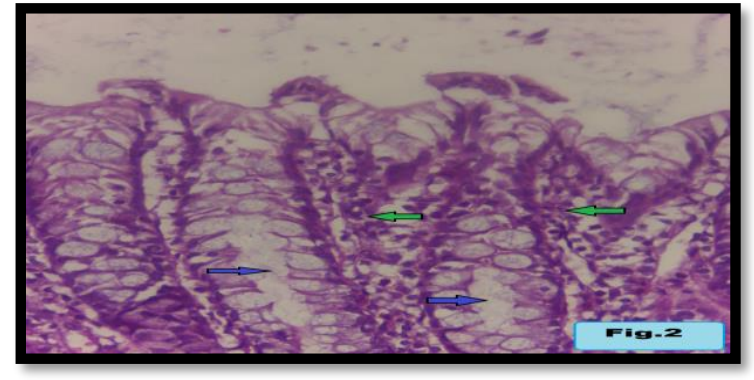

Fig. 2: A Slide of an Adult Rat Intestine in (Group II) Shows the Crowded Villi (Green Arrows) with Dilated Lumen (Blue Arrows) (Hematoxylin \& Eosin Stain X40)

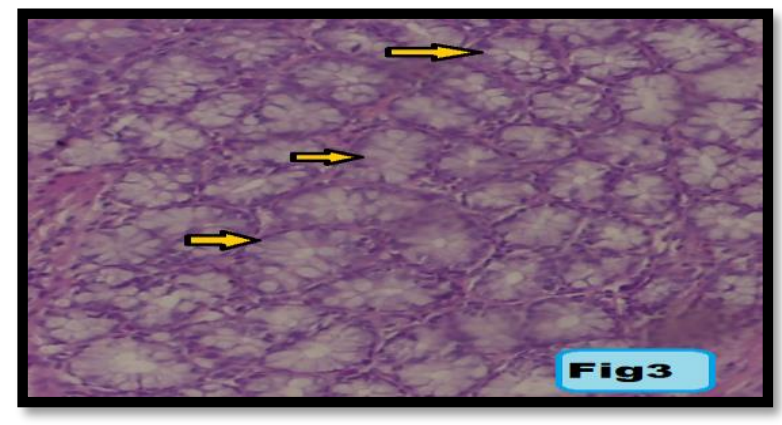

Fig. 3: A Slide of an Adult Rat Intestine in (Group III) Shows Moderate Increase in Goblet Cell Mass (Yellow Arrows) (Hematoxylin \& Eosin Stainx40).

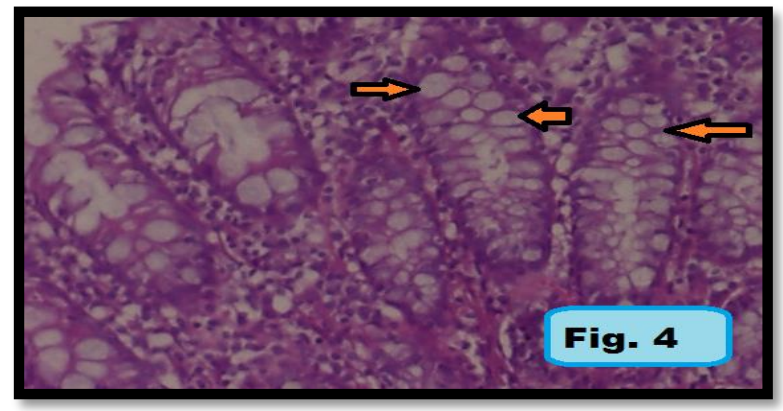

Fig. 4: A Slide of an Adult Rat Intestine in (Group IV) Shows Mild Increase in Goblet Cell Mass (Orange Arrows) (Hematoxalin \&Eosin Stainx40).

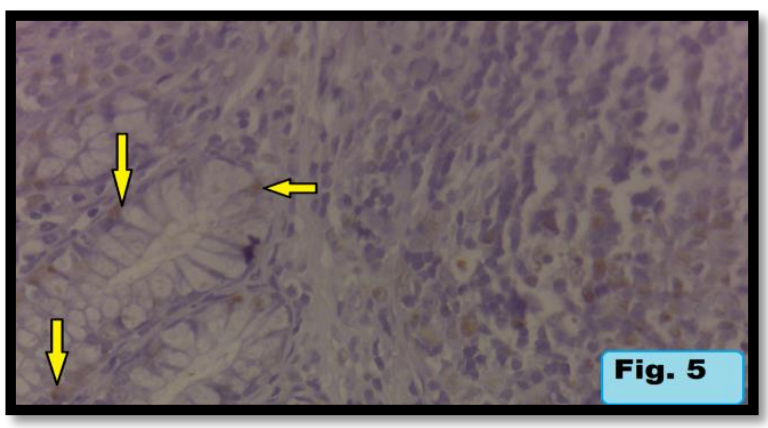

Fig. 5: A Slide of an Adult Rat Intestine in (Group I) Shows That A Few PCNA Positive Cells (Brown Coloration) Were Observed in the Crypt Regions (Yellow Arrows) (Low Expression) (Strept -Avidin -Biotin, X40).

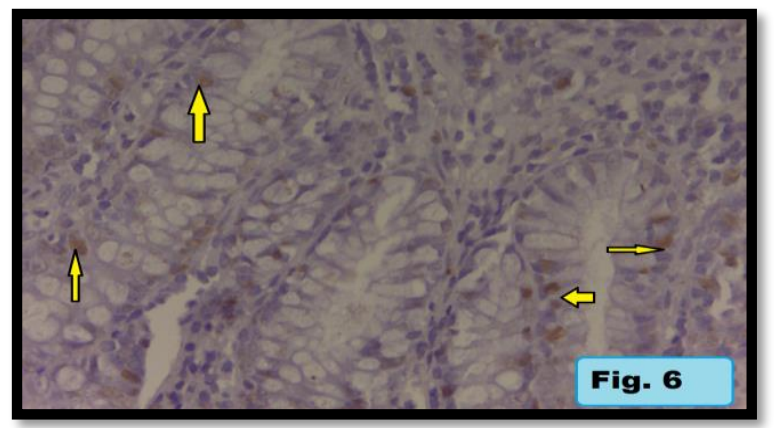

Fig. 6: A Slide of an Adult Rat Intestine in (Group II) Shows That A Few PCNA Positive Cells (Brown Coloration) Were Observed in the Crypt Regions (Yellow Arrows) (Low Expression) (Strept-Avidin-Biotin, X40). 


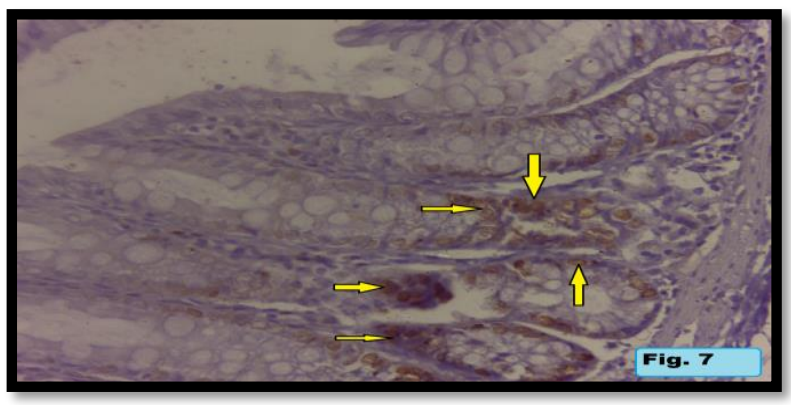

Fig. 7: A Slide of an Adult Rat Intestine in (Group III) Shows the Number of PCNA Positive Cells (Brown Coloration) Was Highly Increased in the Crypt Regions (Yellow Arrows) (High Expression) (Strept -Avidin -Biotin, X40).

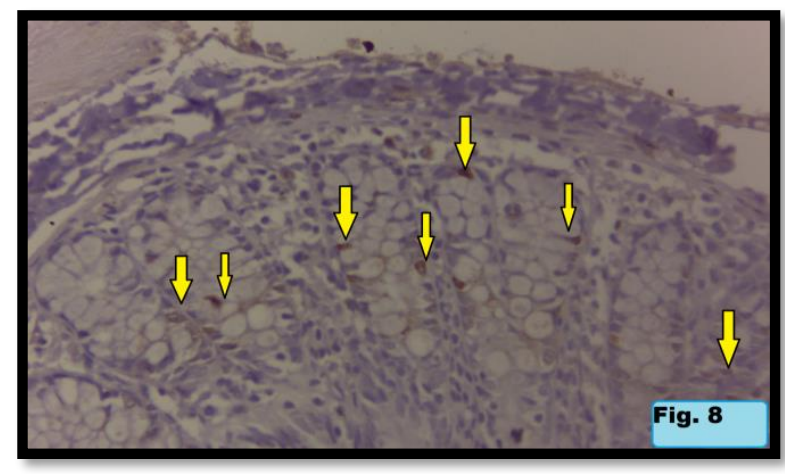

Fig. 8: A Slide of an Adult Rat Intestine in (Group IV) Shows That Concomitant Administration of GTE with Naf Markedly Decrease the Number of PCNA Positive Cells (Brown Coloration) (Yellow Arrows) (Moderate Expression) (Strept -Avidin -Biotin, X40).

\section{Discussion}

In the current study, after 35th day, the final body weight was significantly increased in all groups compared to initial body weight with high significant increase in final body weight in control and GTE groups compared to NaF group. Also, there was significant increase in final body weight in (NaF+GTE) group versus $\mathrm{NaF}$ group and non-significant increase in final body weight in control versus GTE group. These data are in line with Basha and Sujitha (2011) who observed decreased food and water intake and the rate of weight gain was little in rats administrated high fluoride dose in their diet. Also, Shankar et al. (2012) mentioned the that the rate of weight gain was little with decrease in fluoride excretion and increased bone fluoride deposition in animals administrated fluoride in their diet and reported that chronic fluoride intoxication may interfere with calcium absorption by decreasing S100G expression.

The rate of weight gain was little in $\mathrm{NaF}$ group may be due to decreased in appetite leading to decreased consumption of food and water, which lead to decrease in growth. Furthermore, it may be due to primary malnutrition caused by fluoride which displaced other nutrients in the diet and cause secondary malnutrition results from maldigestion or malabsorption of nutrients. In addition, gastrointestinal complications may also change nutritional absorption (Abdel Salam et al., 2013).

Regarding mean Malondialdehyde (MDA) level, the result of the present work reveled that there was a considerable decrease in MDA level in GTE group when compared to the control group, while NaF administration resulted in highly significant increase in MDA level when compared to both the control and GTE group. Concomitant administration of GTE with NaF in the (NaF GTE) group resulted in great improvement representing in a highly significant decrease in MDA level as compared with NaF group.

This result in agreement with the study of Shivarajashankara et al. (2003) that reported that oxidative stress increased in fluoride toxicity which causes increase in malondialdehyde (MDA) levels in red blood cells. Also, in a study done by El-Banna et al. (2019) revealed that concurrent administration of GTE with nicotine can decrease the oxidative stress as green tea polyphenols considered a powerful antioxidant.

Regarding mean reduced GSH level, , the result of the present work reveled that there was a highly significant rise in reduced GSH level in GTE treated rats as compared to control group; $\mathrm{NaF}$ administration resulted in highly significant decrease in reduce GSH level as compared to control and GTE group. Concomitant administration of GTE with NaF leads to highly significant increase in reduce GSH level when compared with $\mathrm{NaF}$ group but still highly significantly lower than the control and GTE groups.

This result is in line with Shivarajashankara et al. (2003) that reported increased levels of total and reduced glutathione in RBCs in fluoride toxicity. Previous studies showed that fluoride increases the liberation of oxygen free radicals and decreases the activity of substances as catalase, superoxide dismutase, and glutathione peroxidase, which have a potent role in antioxidation and removal of free radicals (Yu et al., 2006).

Regarding mean catalase (CAT) level, the result of the present work reveled that there was a highly significant rise in CAT level in GTE treated rats as compared to control group; $\mathrm{NaF}$ administration resulted in highly significant decrease in CAT level as compared to control and GTE group. Concomitant administration of GTE with NaF leads to highly significant elevation in CAT level when compared with $\mathrm{NaF}$ group but still highly significantly lower than the control and GTE groups.

This result is in line with the study of Sara et al. (2018) which reported that cisplatin caused decrease in catalase activity in the intestine that increased by green tea administration. Guney et al. (2007) reported that the decreased CAT level in uterine tissue in rats treated with fluoride due to increased oxidative stress as a result of hydrogen peroxide. Also, Shanthakumari et al. (2004) reported increase in level of lipid peroxides and decrease in the activities of SOD, catalase, glutathione peroxidase and reduced glutathione in fluoride group of rats. A lot of studies have reported that fluoride led to oxidative stress, lipid peroxidation, and reduced antioxidant enzyme activities in vivo or in vitro (Shanthakumari et al., 2004; Shan et al., 2004). Administration of tea polyphenols can improve decreases in antioxidant enzyme 
activities in animal. Administration of green tea polyphenols in the drinking water of mice significantly improved epidermal catalase and glutathione reductase activities (Agarwal et al., 1993).

PCNA known as regulated nuclear protein for DNA-polymerase and the PCNA-labeled nuclei identify the cells in the late G1 and early S phases of the cell cycle and the cells subjected to DNA repair (Itoh et al. 2000; Chen et al. 2005).

In the present work, the immunohistochemical results using PCNA showed that administration of NaF led to highly increase in expression of PCNA and apoptosis in intestinal mucosal cells, however, the administration of green tea extract led to decrease the protein expression of PCNA and apoptosis in these cells.

Anuradha et al. (2001) reported that $\mathrm{NaF}$ may causes apoptosis through lipid peroxidation resulted from oxidative stress leading to release of cytochrome $\mathrm{C}$ in the cytosol and trigger the caspase causing apoptotic cell death. Furthermore, there is relationship between DNA damage, apoptosis and lipid peroxidation caused by fluoride (Wang et al., 2004).

Sara et al. (2018) founded that cisplatin caused significant changes in intestinal mucosal membrane and green tea administration caused improvement of these changes due to its antioxidant activities.

Liu et al (2003) reported that the mechanism of fluoride toxicity may be that fluoride causes increase in production of nitric oxide, lipid peroxides or oxygen free radicals that lead to reduced ability to remove the free radicals and decrease the antioxidation which strongly lead to injury to the structure specially the biological membrane, proteins, nuclei acids, the soft tissues and affect the cells functions. Matsui et al. (2007) founded that $\mathrm{NaF}$ increased intracellular $\mathrm{Ca} 2+$ concentration and significantly increased the number of shrunken cells which are the early stage of apoptosis and reported that NaF causes necrosis with some apoptotic alterations. Stawiarska-Pięta et al. (2012) also reported that the administration of antioxidants improved the changes in the enzymes and the morphological changes of the liver caused by $\mathrm{NaF}$.

Green tea extract known to increase antioxidative enzymes and act as antioxidants to remove reactive oxygen species (Forester and Lambert, 2011). Furthermore, Sinha et al., (2007) revealed that green tea extract causes DNA repair by the high expression of DNA repair enzymes. Also Han et al. (2011) reported significant decrease in DNA damage with GTE intake for 28 days. Pandurangan et al (2012) revealed that green tea extract can protect from genotoxicity and lipid peroxidation in rats.

\section{Conclusion}

From the results of the present study it can be concluded that the use of green tea extract (GTE) improved the biochemical, histopathological and immunohistochemical changes that occur in the intestinal mucosa by fluoride (NaF) administrated and could be attributed to oxidative stress state.

\section{Conflicts of interest}

The authors had no conflicts of interest to declare in relation to this article.

\section{References}

[1] Abdel Salam G, Mehlab EM, Al-Shishtawy M, Al-Zahrani I (2013): Ameliorative Effects of Selenium and Vitamins C and E on Chronic Fluoride Pancreatic Toxicity: Structural and Ultrastructural Changes in Albino Rats; Journal of American Science; 9(3):274-383.

[2] Aebi H (1984): Catalase. In: Bergmeyer HU (ed.) Methods of Enzymatic Analysis. New York: Academic Press; $673-684$. https://doi.org/10.1016/B978-0-12-091302-2.50032-3.

[3] Agarwal, R, Katiyar SK, Khan SG, Mukhtar H (1993): Protection against ultraviolet B radiation-induced effects in the skin of SKH-1 hairless mice by a polyphenolic fraction isolated from green tea. Photochem. Photobiol, 58, 695-700. https://doi.org/10.1111/j.1751-1097.1993.tb04954.x.

[4] Anuradha CD, Kanno S, Hirano S (2001): Oxidative damage to mitochondria is a preliminary step to caspase-3 activation in fluoride-induced apoptosis in HL-60 cells. Free Radic Biol Med; 31(3):367-373. https://doi.org/10.1016/S0891-5849(01)00591-3.

[5] Asfar S, Abdeen S, Dashti H, Khoursheed M, Al-Sayer H, Mathew T et al. (2003): Effect of green tea in the prevention and reversal of fastinginduced intestinal mucosal damage. Nutrition; 19: 536-540. https://goo.gl/rqZcCp https://doi.org/10.1016/S0899-9007(02)01097-3.

[6] Bancroft J and Stevens A (1996): Theory and practice of histological techniques, 4th edition. Churchill Livingstone, NY. Pp: 276-279.

[7] Bancroft JD and Stevens GA (1990): Theory and Practice of Histological Techniques. 2nd Ed. Churchill Livingstone, London 1990.

[8] Barnham KJ, Masters CL, Bush AI (2004): Neurodegenerative diseases and oxidative stress. Nature Reviews Drug Discovery (3): $205-214$. https://doi.org/10.1038/nrd1330.

[9] Basha MP and Sujitha NS (2011): Chronic Fluoride Toxicity and Myocardial Damage: Antioxidant Offered Protection in Second Generation Rats. Toxicol Int.; 18(2): 99-104. https://doi.org/10.4103/0971-6580.84260.

[10] Beutler E, Duron O, Kelly BM (1963): Improved method for the determination of blood glutathione. J.Lab. Clin. Med; 61: 882-888.

[11] Błaszczyk I, Grucka-Mamczar E, Kasperczyk S, Birkner E (2008): Influence of fluoride on rat kidney antioxidant system: effects of methionine and vitamin E. Biol Trace Elem Res.; 121(1):51- 59. https://doi.org/10.1007/s12011-007-8030-6.

[12] Bouaziz H, Ketata K, Jammoussi T, Boudawara F, Ayedi F, Ellouze N (2006): Effects of sodium fluoride on hepatic toxicity in adult mice and their suckling pups, pestic. Biochem. Physiol.; 86: 124-130. https://doi.org/10.1016/j.pestbp.2006.02.004.

[13] Chachra D, Vieira AP, Grynpas MD (2008): Fluoride and mineralized tissues, Critical Reviews in Biomedical Engineering; 36(2-3): 183-223. https://doi.org/10.1615/CritRevBiomedEng.v36.i2-3.40.

[14] Chen W, Fu XB, Ge SL, Sun TZ, Li WJ, Sheng ZY (2005): Acid fibroblast growth factor reduces rat intestinal mucosal damage caused by ische$\mathrm{mia} /$ reperfusion insult. World J Gastroenterol 11:6477-6482. https://doi.org/10.3748/wjg.v11.i41.6477.

[15] El-Banna Asmaa S, Badr El Dine Fatma Mohamed Magdy, Abd El Halim Riham (2019): Assessment of protective role of green tea extract (GTE) and N-acetylecysteine (NAC) against the potential genotoxicity of nicotine in adult male albino rats, Egypt J. Forensic Sci. Appli. Toxicol. 19 (1):1-16. https://doi.org/10.21608/ejfsat.2019.6394.1034.

[16] Finkel T and Holbrook NJ (2000): Oxidants, oxidative stress and the biology of ageing. Nature, 408, 239-247. https://doi.org/10.1038/35041687.

[17] Forester SC and Lambert JD (2011): Antioxidant effects of green tea. Mol Nutr Food Res. 55(6): 844-854. https://doi.org/10.1002/mnfr.201000641.

[18] Goto K, Kanaya S, Nishikawa T (1998): Green tea catechins improve the gut flora. Ann Long-Term Care; 6: 1-7.

[19] Greenberg R S, Daniels R S, Flanders WD, et al. (1996): Diagnostic Testing. In: Medical Epidemiology. McGraw-Hill, New York, NY, 3rd ed., chapter (4): 77-89.

[20] Guney Mehmet, Oral Baha, Demirin, Karahan Hilmi Nermin, Mungan Tamer and Delibas Namik (2007): protective effects of vitamins c and E against endometrial damage and oxidative stress in fluoride intoxication,Clinical and Experimental Pharmacology and Physiology; (34): 467-474. https://doi.org/10.1111/j.1440-1681.2007.04596.x. 
[21] Gupta S, Saha B, Giri AK (2002): Comparative antimutagenic and anticlastogenic effects of green tea and black tea: a review. Mutation Research, 512, 37-65. https://doi.org/10.1016/S1383-5742(02)00024-8.

[22] Hall P, Levison D, Woods A et al. (1990): Proliferating cell nuclear antigen (PCNA) immunolocalization in paraffin sections: an index of cell proliferation with evidence of deregulated expression in some neoplasms. J Pathol; 162: 285-294. https://doi.org/10.1002/path.1711620403.

[23] Hamdy MA, El-Maraghy SA, Kortam MA. (2012): Modulatory effects of curcumin and green tea extract against experimentally induced pulmonary fibrosis: a comparison with N-acetyl cysteine. J Biochem Mol Toxicol. 26 (11): 461-468. https://doi.org/10.1002/jbt.21447.

[24] Han KC, Wong WC, Benzie IFF. (2011): Genoprotective effects of green tea (Camellia Sinensis) in human subjects: results of a controlled supplementation trial. Br J Nutr 1: 1-8.

[25] Itoh H, Yagi M, Fushida S, Tani T, Hashimoto T, Shimizu K, Miwa K (2000): Activation of immediate early gene, c-fos, and c-jun inthe rat small intestine after ischemia/reperfusion. Transplantation 69:598. https://doi.org/10.1097/00007890-200002270-00022.

[26] Khan N and Mukhtar H (2007): Tea polyphenols for health promotion. Life Sci.; 81: 519-533. https://goo.gl/dt3QkQ https://doi.org/10.1016/j.lfs.2007.06.011.

[27] Liu G Y, Chai C Y, Li C (2003): Fluoride causing abnormally elevated serum nitric oxide levels in chicks. Environ Toxicol Phar; (13):199-204. https://doi.org/10.1016/S1382-6689(03)00002-4.

[28] Lowry OH, Rosenbrough NJ, Farr AC, Randall RJ (1951): Protein measurement with the folin phenol regent. J Biol Chem; $193: 265-275$.

[29] Matsui H, Morimoto M, Horimoto K, Nishimura Y (2007): Some characteristics of fluoride-induced cell death in rat thymocytes: cytotoxicity of sodium fluoride. Toxicol In Vitro; 21(6):1113-1120. https://doi.org/10.1016/j.tiv.2007.04.006.

[30] Ohkawa H, Oshishi N, Yagi K (1979): Assay of lipid peroxidation in animal tissue by thiobarbituric acid reaction. Anal Biochem; (95):351-358. https://doi.org/10.1016/0003-2697(79)90738-3.

[31] Ozsvath DL (2009): Fluoride and environmental health: a review. Reviews in Environmental Science and Biotechnology; 8(1): 59-79. https://doi.org/10.1007/s11157-008-9136-9.

[32] Pandurangan AK, Periasamy S, Anandasadagopan SK, Ganapasam S, Srinivasalu SD (2012): Green tea polyphenol protection against 4nitroquinoline 1-oxide-induced bone marrow lipid peroxidation and genotoxicity in Wistar rats. Asian Pac J Cancer Prev. 13 (8): $4107-4112$. https://doi.org/10.7314/APJCP.2012.13.8.4107.

[33] Perwez H S, Hofseth LJ, Harris CC (2003): Radical cause of cancer. Nature Reviews. Cancer (3):276 - 285. https://doi.org/10.1038/nrc1046.

[34] Rameshrad M, Razavi BM, Hosseinzadeh H (2017): Protective effects of green tea and its main constituents against natural and chemical toxins: A comprehensive review. Food Chem Toxicol.; 100: 115-137. https://goo.gl/dKTYmE https://doi.org/10.1016/j.fct.2016.11.035.

[35] Sara AK, Shubha P, Sheeba K, Md Wasim K, and Ahad NK Yusufi (2018): Green Tea Consumption Ameliorates Intestinal and Hepatic -Toxicity induced by Long-Term administration of Cisplatin International Journal of Drug Metabolism \& Toxicology, 2 (1):2-9.

[36] Shan KR, Qi XL, Long YG, Nordberg A, Guan ZZ (2004): Decreased nicotinic receptors in PC12 cells and rat brains influenced by fluoride toxicity - a mechanism relating to damage at the level in post-transcription of the receptor genes. Toxicology; 200: 169-77. https://doi.org/10.1016/j.tox.2004.03.013.

[37] Shankar P, Ghosh S, Bhaskarachary K, Venkaiah K, Khandare AL (2012): Amelioration of chronic fluoride toxicity by calcium and fluoride-free water in rats. Br J Nutr. (11):1-10. https://doi.org/10.1017/S0007114512004758.

[38] Shanthakumari D, Srinivasalu S, Subramanian S (2004): Effect of fluoride intoxication on lipid peroxidation and antioxidant status in experimental rats. Toxicology; 204(2-3): 219-228. https://doi.org/10.1016/j.tox.2004.06.058.

[39] Shimizu M. (1999): Modulation of intestinal functions by food substances. Nahrung.; 43: 154-158. https://goo.gl/tvysZS. https://doi.org/10.1002/(SICI)1521-3803(19990601)43:3<154::AID-FOOD154>3.0.CO;2-A

[40] Shivarajashankara YM, Shivashankara AR, Bhat PG, Rao SH (2003): Lipid peroxidation and antioxidant systems in the blood of young rats subjected to chronic fluoride toxicity. Indian J Exp Biol.; 41(8):857-60.

[41] Sinha D, Dey S, Bhattacharya RK, Roy M (2007): In vitro mitigation of arsenic toxicity by tea polyphenols in human lymphocytes. J Environ Pathol Toxicol Oncol 26: 207-220. https://doi.org/10.1615/JEnvironPatholToxicolOncol.v26.i3.50.

[42] Stawiarska-Pieta B, Bielec B, Birkner K, Birkner E (2012): The influence of vitamin E and methionine on the activity of enzymes and the morphological picture of liver of rats intoxicated with sodium fluoride. Food and Chemical Toxicology, 50(3-4): 972-978. https://doi.org/10.1016/j.fct.2012.01.014.

[43] Stawiarska-Pięta B, Bielec B, Birkner K, Birkner E (2012): The influence of vitamin E and methionine on the activity of enzymes and the morphological picture of liver of rats intoxicated with sodium fluoride. Food Chem Toxicol.; 50(3-4):972-978. https://doi.org/10.1016/j.fct.2012.01.014.

[44] Wang A G, Xia T, Chu Q L, et al. (2004): Effects of fluoride on lipid peroxidation, DNA damage and apoptosis in human embryo hepatocytes. Biomed Environ Sci 17(2): 217-222.

[45] Wang SX, Wang ZH, Cheng XT, et al. (2007): “Arsenic and fluoride expose in drinking water: children's IQ and growth in Shanyin Country, Shanxi Province, China," Environmental Health Perspectives; 115(4): 643-647. https://doi.org/10.1289/ehp.9270.

[46] Xiang Q, Liang Y, Chen Y, et al. (2003): Effect of fluoride in drinking water on children's intelligence. Fluoride; 36(2): 84-94.

[47] Yu RA, Xia T, Wang AG, Chen XM (2006): Effects of selenium and zinc on renal oxidative stress and apoptosis induced by fluoride in rats. Biomed Environ Sci.; 19(6):439-444. 